\title{
GT BIPLOT ANALYSIS FOR YIELD AND RELATED TRAITS IN SOME SUGAR BEET VARIETIES AS AFFECTED BY COMPOST UNDER SALINE SOIL
} Abu-Ellail, F.F.B. ${ }^{1 *}$ and A. H. Sasy ${ }^{2}$

${ }^{1}$ Breeding and Genetics Dept., ${ }^{2}$ Sugar Technology, Res. Dept., Sugar Crops Research Institute, Agriculture Research Center, Giza, Egypt. 1*Email - farrag_abuellail@yahoo.com

Key Words: Compost fertilizer, Correlation, GT biplot, Mono and Multigerm Sugar Beet Varieties.

\section{ABSTRACT}

Two field trials were carried out during two successive seasons of $2018 / 2019$ and 2019/2020 at farmer's field, Tamiya, (latitude of $29.58^{\circ}$ $\mathrm{N}$, longitude of $30.96^{\circ} \mathrm{E}$ and altitude of $34 \mathrm{~m}$ above sea level), Al Fayoum Governorate, Egypt, to evaluate the performance of eight sugar beet varieties under four levels of compost (without, 2, 4, and 6 ton /fed) in saline soil. A split-plot design with three replications was used in both seasons. The results revealed that treating the soil with 6-ton compost/fed significantly increased root diameter, root fresh weight/plant, sucrose and extractable sugar percentages, sodium content, root and sugar yields/fed as well as alpha-amino $\mathrm{N}$ content decreased in both seasons. Meantime, the proline, potassium, sodium contents and sugar lost to molasses\% were insignificantly affected by compost levels in $1^{\text {st }}$ season and the second one. Indira-KWS mono-germ variety exhibited superiority over the all other tested varieties, which recorded the highest values of root diameter, root fresh weight/plant, sucrose $\%$, root and sugar yields/fed as well a significant decrease in proline content in both seasons. While, both mono-germ Carma variety and multi-germ Shrb 21802 variety had the lowest value of sodium content without significant difference between them in both seasons, compared with the other varieties. There was a highly significant and positive correlation between root yield and each root diameter and root weight. The genotype by trait (GT) biplot graph was used to compare varieties based on multiple traits. It proved to be a reliable and easy-to-interpret analysis and visualization of the results. interpret analysis and visualization of the results. Under conditions of this work, planting mono-germ variety (Indira-KWS) and fertilized it with 6ton compost/fed can be recommended to get the higher root and sugar yields/fed under saline soil condition.

\section{INTRODUCTION}

Most soils in Al-Fayum governorate are affected by soil salinity very around Lake Qaroun in large areas connected to most of the city, such as Tamiya, also the salt rates range from $2 \mathrm{dsm}^{-1}$ to $17 \mathrm{dsm}^{-1}$ and have a significant impact on the growth of crops and reduce agricultural 
production in general. Evaluate imported sugar beet varieties under saline soil is essential to select recommended best variety under these conditions. Also, to cultivate this soil, need good fertilizing and good agricultural practices to be available for planting.

Sugar beet (Beta vulgaris L.) is one of the most important crops for sugar production in Egypt, and it has the ability to grown on newly reclaimed soils that suffer from salinity. Sugar beet became an important crop in the newly reclaimed sandy and saline soils, increasing sugar crops cultivated area and sugar production per unit area is considered the important national target to minimize the gap between sugar consumption and production. The total sugar beet cultivated area reached about 5985 thousand fed., with an average of 18 tons fed $^{-1}$ (Annual Report of Sugar Crops Council, December 2020). Recently, the sugar beet crop has been of favorable importance in local crop rotation as a winter crop not only infertile soils but also in poor, saline, alkaline and calcareous soils. Moreover, it could be economically grown in newly reclaimed soils. Nowadays, compost is being extensively used as a robust tool to maximize crop productivity. Deficiency of soil nutrients such as nitrogen, phosphorus, potassium, zinc and boron has been identified as the major constraints in sugar beet crop production and, based on plant needs, should be added to the soil (Ali, 2015).

Soil salinity is a major abiotic stress that has adverse effects on the physiological and metabolic processes of plants leading to diminished growth and yield of plants (Azizpour et al., 2010). Plant growth is suppressed severely at high salinity stress due to factors such as osmotic stress, mineral nutrition absorption imbalance, and specific ion toxicity, all combining to reduce nutrient uptake consequentially causing physiological drought to plants (David, 2007). Fertilization plays an important role in promoting plants to tolerate salt stress and specialize from this fertilization compost which, has a positive effect on soil fertility as well as the productivity of the field crops. Hence, adding significant quantities of agricultural residues as compost in saline sandy soils improves their physical, chemical and biological properties. In this connection, Wallace and Carter (2007) showed that the use of compost increases soil fertility which led to increasing sugar beet root yield by 7\%. Siddiqui et al., (2009) explained that compost is an organic soil amendment and is an important source of fertilization, which is found as a result of organic material decomposition. Also, compost is improving the soil's physical and chemical properties and increasing water holding capacity. El-Nagdi and Abd El Fattah (2011) showed that all plant residues, bio fertilizer, and organic compost alone or in combination with biocides significantly increased the fresh weight of roots and shoots of sugar beet plants. Compost is a low cost as organic fertilizers and soil 
amendment. When applied to soils, it positively affects the structure, porosity, water holding capacity, nutrient contents and organic matter all of which improve plant growth and crop yield (Rajaa and Saadi, 2011). Masri et al., (2015) found that adding compost (2 ton/fed) gave the maximum values of root yield, as well as improved juice quality traits of sugar-beet. Also, the application of 12 tons/ha of compost improved the root yield of sugar beet. As for the differences between varieties, Enan, et al., (2016) and Makhlouf et al., (2021) indicated that the tested beet varieties differed significantly in the studied traits. The aim of this work is to evaluate eight sugar beet varieties that fertilized with different compost levels for growth, yield, and technological traits. Also, estimate GT biplot analysis and estimate the correlation coefficient between yield and related traits were investigated.

\section{MATERIALS AND METHODS}

Two field trials were carried out during two successive seasons of $2018 / 2019$ and 2019/2020 at farmer's field, Tamiya, (latitude of $29.58^{\circ}$ $\mathrm{N}$, longitude of $30.96^{\circ} \mathrm{E}$ and altitude of $34 \mathrm{~m}$ above sea level) $\mathrm{Al}$ Fayoum Governorate, Egypt, to evaluate the performance of eight sugar beet varieties namely (Indira, Dipendra, Carma and Vangelis) as a multigerm variety and (Shantala, Melodia, MK 4199 and Shrb21802) as a monogram variety under four levels of compost (without, 2, 4, and 6 ton /fed) in saline soil. A split-plot design with three replications was used in both seasons. The four levels applied of compost fertilization allocated in the main plots and the eight tested varieties were randomly distributed in the sub-plots. The plot area was $18 \mathrm{~m}^{2}$, which included 5 ridges of $6.0 \mathrm{~m}$ in length and $0.6 \mathrm{~m}$ in width. Compost was applied before sowing during seedbed preparation. Phosphorous was added in the form of superphosphate $(15 \%)$ at the rate of $30 \mathrm{~kg} \mathrm{P}_{2} \mathrm{O}_{5} /$ fed during seedbed preparation. Nitrogen fertilizer was added in the form of ammonium nitrate $(33.5 \% \mathrm{~N})$ at the rate of $80 \mathrm{~kg} \mathrm{~N} /$ fed in three equal doses; after thinning (4 true leaf stage) and after 3-week intervals later. Potassium was added in the form of potassium sulfate (48\%) at the rate of $48 \mathrm{~kg}$ $\mathrm{K}_{2} \mathrm{O} /$ fed with the first and third dose of nitrogen fertilizer. Multi-germ and mono-germ sugar beet varieties were sown in the $2^{\text {nd }}$ week of October in the $1^{\text {st }}$ and $2^{\text {nd }}$ seasons, while harvesting took place at age of 210 days after sowing in both seasons. All other cultural practices were maintained to assure optimum growth and production throughout the whole season. The country of origin of the tested sugar beet varieties is manifested in Table (1). The chemical properties and contents of the plant compost are presented in Table (2). As shown by Jackson (1958), soil samples were taken for mechanical and chemical analyses before 
sowing from each location at $0-30 \mathrm{~cm}$ depth from the soil surface (Table $3)$.

Table 1: Country of origin and source* of the evaluated sugar beet (Beta vulgaris var. saccharifera, L.) varieties

\begin{tabular}{|l|l|l|l|}
\hline Sugar beet varieties & Types & Company & Country of origin \\
\hline Indira -KWS & Monogerm & KWS & Germany \\
\hline Dipendra-KWS & Monogerm & KWS & Germany \\
\hline Carma & Monogerm & MARIBO & Denmark \\
\hline Vangelis & Monogerm & SCHREIBOERS & USA \\
\hline Shantala-KWS & Maltigerm & KWS & Germany \\
\hline Melodia & Maltigerm & KHBC & Poland \\
\hline MK 4199(Emperator) & Maltigerm & KUHN & USA \\
\hline Shrb21802(Echnaton) & Maltigerm & STRUBE & Netherlands \\
\hline
\end{tabular}

*Source: Sugar Crops Research Institute, Agricultural Research Centre, Giza, Egypt

Table 2: Chemical properties of compost plant

\begin{tabular}{|l|l|l|l|l|l|l|l|l|c|c|c|}
\hline $\begin{array}{l}\text { Moisture } \\
\text { content }\end{array}$ & $\begin{array}{l}\mathrm{EC} \\
\mathrm{dSm}^{-1} \\
1: 10\end{array}$ & $\mathbf{P H}$ & $\begin{array}{l}\text { C/N } \\
\text { ratio }\end{array}$ & $\begin{array}{l}\text { Organic } \\
\text { Matter }\end{array}$ & $\begin{array}{c}\text { Organic } \\
\text { carbon }\end{array}$ & Ashe & $\begin{array}{c}\text { Ammonium } \\
\text { nitrogen }\end{array}$ & $\begin{array}{c}\text { Nitrate } \\
\text { nitrogen }\end{array}$ & $\begin{array}{c}\text { Total } \\
\text { nitrogen }\end{array}$ & $\begin{array}{c}\text { Total } \\
\text { phosphoric }\end{array}$ & $\begin{array}{c}\text { Total } \\
\text { potassium }\end{array}$ \\
\hline $21 \%$ & 2.65 & 6.5 & $1: 20$ & $41.85 \%$ & $37.9 \%$ & $35.9 \%$ & $320 p p m$ & $22 p p m$ & $2.77 \%$ & $1.09 \%$ & $0.64 \%$ \\
\hline
\end{tabular}

Table 3: Soil properties of the experimental site in 2018-2019 and 20192020 seasons

\begin{tabular}{|c|c|c|}
\hline Particle size distributions & 2018/2019 season & 2019/2020 season \\
\hline Sand\% & 33.15 & 28.52 \\
\hline Silt\% & 45.32 & 47.23 \\
\hline Clay \% & 21.53 & 24.25 \\
\hline Texture & Sandy loam & Sandy loam \\
\hline $\begin{array}{l}\text { pH at (1:2.5) soil: } \text { water } \\
\text { suspension }\end{array}$ & 8.2 & 7.4 \\
\hline EC $(d S / m)$ & 6.18 & 6.00 \\
\hline O.M (g/kg) & 6.69 & 8.23 \\
\hline $\mathrm{CaCO3}$ (g/kg) & 84.69 & 80.45 \\
\hline \multicolumn{3}{|l|}{ Cations (meq/l) } \\
\hline $\mathrm{Na}+$ & 41.28 & $39 . .92$ \\
\hline $\mathbf{K}+$ & 1.96 & 1.58 \\
\hline $\mathrm{Ca}++$ & 8.77 & 6.83 \\
\hline $\mathrm{Mg}++$ & 9.89 & 8.57 \\
\hline \multicolumn{3}{|l|}{ Anions (meq/l) } \\
\hline Cl- & 36.85 & 32.22 \\
\hline HCO3- & 12.61 & 11.15 \\
\hline So4- & 12.44 & 13.53 \\
\hline \multicolumn{3}{|l|}{ Available NPK (mg/kg soil) } \\
\hline Available Nitrogen & 11.19 & 46.31 \\
\hline Available $\mathrm{P}_{2} \mathrm{O}_{5}$ & 4.35 & 6.78 \\
\hline Available $\mathrm{K}_{2} \mathrm{O}$ & 155.21 & 165.26 \\
\hline
\end{tabular}




\section{The recorded data:}

After 105 days from sowing, random samples of sugar beet plants were taken from each sub plot to determine the following traits:

1. Proline concentration (u moles/g leaf fresh weight) was estimated using the method of Bates et al., (1973).

At harvest, a sample of ten plants was randomly collected from the middle rows of each plot to determine the following traits:

1. Root diameter $(\mathrm{cm})$.

2. Root fresh weight/plant (g)

3. Sucrose (Pol \%) was estimated in the fresh samples of sugar beet roots using Saccharometer according to the method described by A.O.A.C. (2005)

4. Impurities (K, Na and $\alpha$-amino $\mathrm{N})$ in roots were determined in El-Fayoum Sugar Company Laboratories, by an Automated Analyzer as described by Cooke and Scott (1993).

5. Sugars lost to molasses percentage (SLM \%) was calculated according to the following formula as shown by Devillers (1988): $\mathrm{SLM} \%=0.14(\mathrm{Na}+\mathrm{K})+0.25(\alpha$-amino $\mathrm{N})+0.5$

6. Extracted sugar percentage was calculated according the formula of Dexter et al., (1967) as follows:

Extracted sugar \% = sucrose $\%$ - SLM $\%-0.6$

7. Quality index $(\mathrm{QZ} \%)=($ extracted sugar $\% /$ sucrose $\%) \times 100$.

8. Root yield/fed (ton), which were determined on sub plot weight $(\mathrm{kg})$ and converted to tons/fed.

9. Sugar yield/fed (ton) was calculated according to the following method of Devillers (1988): Sugar yield/fed (ton) $=$ root

\section{Statistical analysis} yield/fed (ton) x extracted sugar\% /100

Results were statistically analyzed using COSTATC software. The ANOVA test was used to determine significantly $(p \leq 0.01$ or $p \leq 0.05)$ treatment effect and LSD was used to compare among treatment means. Yan and Rajcan (2002) used the genotype by trait (GT) biplot, which is an application of the GGE biplot to study the genotype by trait data. Because the traits were measured in different units, the biplot procedure was generated using the standardized values of the trait means. SPSS version 10 was used for assessing the magnitudes of correlation among variables. Phenotypic correlation coefficients were calculated among all the traits according to (Falconer, 1989).

\section{RESULTS AND DISCUSSIONS}

Effect of the tested sugar beet varieties:

Except for potassium and alpha-amino nitrogen contents, sugar lost to molasses\%, and quality index data in Table 4 indicated that the tested sugar beet varieties differed significantly in proline content, root 
diameter, fresh weight/plant, sucrose, and extractable sugar percentages, as well as sodium content, root and sugar yields/fed in both seasons. Indira-KWS mono-germ variety recorded a significant decreased in proline content. These results may be due to the positive correlation between proline accumulation and plant stress where it plays a beneficial role in plants exposed to various stress conditions. At the same time, it surpassed the other varieties, whether it is mono or multigerm seeds, with respect to root diameter, root fresh weight/plant, sucrose\%, root, and sugar yields/fed. While, both mono-germ Carma and multi-germ Shrb 21802 varieties had the lowest value of sodium content without significant difference between them in both seasons, compared with the other varieties. This result may be attributed to that plant growth, development, and finally, the yield of root and sugar which is the result of genetic composition and environmental effects. Sugar beet varieties markedly differed significantly root fresh weight per plant, root and sugar yields, as well as sucrose\% and extractable sugar\% (Enan et al., 2016, Abu-Ellail et al., 2020 and El-Kady et al., 2021).

Table 4: Some traits of the tested sugar beet varieties as affected by compost levels in 2018/2019 and 2019/2020 seasons.

\begin{tabular}{|c|c|c|c|c|c|c|c|c|c|c|c|c|}
\hline \multirow{3}{*}{$\begin{array}{c}\text { Sugar beet } \\
\text { varieties }\end{array}$} & \multicolumn{12}{|c|}{ 2018/2019 season } \\
\hline & \multirow{2}{*}{$\begin{array}{c}\text { Proline } \\
(\mu \text { moles } / g)\end{array}$} & \multirow{2}{*}{$\begin{array}{c}\text { RD } \\
(\mathrm{cm})\end{array}$} & \multirow{2}{*}{$\begin{array}{l}\text { RW } \\
\text { (kg) }\end{array}$} & \multirow[t]{2}{*}{ S\% } & Alpha & $\begin{array}{ll}\mathrm{Na} \\
\end{array}$ & $\mathbf{K}$ & \multirow[t]{2}{*}{ SLM\% } & \multirow[t]{2}{*}{ ES\% } & \multirow[t]{2}{*}{$\mathbf{Q Z}$} & \multirow{2}{*}{$\begin{array}{c}\text { RY } \\
\text { (ton/fed) }\end{array}$} & \multirow{2}{*}{$\begin{array}{c}\text { SY } \\
\text { (ton/fed) }\end{array}$} \\
\hline & & & & & \multicolumn{3}{|c|}{$\begin{array}{c}\text { contents } \\
\text { (meq/100 g) } \\
\text { (beet) }\end{array}$} & & & & & \\
\hline Indira & 2.40 & 11.04 & 0.876 & 16.25 & 1.43 & 2.61 & 2.65 & 1.59 & 14.06 & 86.52 & 20.72 & 2.91 \\
\hline Dipendra & 3.10 & 10.16 & 0.631 & 15.87 & 1.49 & 2.50 & 2.65 & 1.59 & 13.68 & 86.20 & 18.85 & 2.58 \\
\hline Carma & 3.20 & 10.26 & 0.666 & 15.56 & 1.46 & 2.37 & 2.57 & 1.56 & 13.40 & 86.12 & 20.17 & 2.70 \\
\hline \begin{tabular}{|l|} 
Vangelis \\
\end{tabular} & 3.50 & 9.81 & 0.621 & 15.98 & 1.48 & 2.31 & 2.41 & 1.53 & 13.85 & 86.67 & 18.76 & 2.60 \\
\hline Shantala & 3.20 & 10.56 & 0.705 & 16.33 & 1.22 & 2.21 & 2.55 & 1.47 & 14.26 & 87.32 & 18.64 & 2.64 \\
\hline Melodia & 2.90 & 10.57 & 0.864 & 15.68 & 1.51 & 2.15 & 2.85 & 1.58 & 13.50 & 86.10 & 19.57 & 2.66 \\
\hline MK 4199 & 3.10 & 10.36 & 0.695 & 15.59 & 1.53 & 2.24 & 2.74 & 1.58 & 13.41 & 86.02 & 19.47 & 2.61 \\
\hline \begin{tabular}{|l|} 
Shrb21802 \\
\end{tabular} & 2.90 & 10.19 & 0.690 & 15.59 & 1.76 & 2.36 & 2.37 & 1.60 & 13.39 & 85.89 & 19.22 & 2.57 \\
\hline LSD at 5\% & 0.32 & 0.15 & 0.04 & 0.08 & NS & 0.10 & NS & NS & 0.14 & NS & 0.26 & 0.03 \\
\hline \multicolumn{13}{|c|}{$2019 / 2020$ season } \\
\hline Indira & 1.50 & 10.96 & 0.699 & 17.14 & 1.43 & 2.50 & 2.62 & 1.57 & 14.97 & 87.34 & 20.45 & 3.06 \\
\hline Dipendra & 2.50 & 10.18 & 0.618 & 16.04 & 1.49 & 2.41 & 2.63 & 1.58 & 13.86 & 86.41 & 19.18 & 2.63 \\
\hline Carma & 2.30 & 10.21 & 0.653 & 16.07 & 1.46 & 2.23 & 2.54 & 1.55 & 13.92 & 86.62 & 19.74 & 2.75 \\
\hline \begin{tabular}{|l|} 
Vangelis \\
\end{tabular} & 2.20 & 9.78 & 0.589 & 16.68 & 1.41 & 2.33 & 2.38 & 1.51 & 14.57 & 87.35 & 19.00 & 2.79 \\
\hline Shantala & 2.10 & 10.56 & 0.677 & 16.54 & 1.22 & 2.38 & 2.53 & 1.47 & 14.47 & 87.48 & 18.44 & 2.72 \\
\hline Melodia & 2.10 & 10.67 & 0.691 & 16.14 & 1.51 & 2.39 & 2.82 & 1.58 & 13.96 & 86.49 & 19.51 & 2.79 \\
\hline MK 4199 & 1.90 & 10.15 & 0.645 & 16.03 & 1.53 & 2.27 & 2.71 & 1.58 & 13.85 & 86.40 & 19.25 & 2.67 \\
\hline \begin{tabular}{|l|} 
Shrb21802 \\
\end{tabular} & 2.10 & 10.19 & 0.617 & 16.27 & 1.51 & 2.26 & 2.34 & 1.54 & 14.13 & 86.85 & 19.78 & 2.65 \\
\hline LSD at $5 \%$ & 0.23 & 0.13 & 0.07 & 0.05 & NS & 0.13 & NS & NS & 0.16 & NS & 0.12 & 0.12 \\
\hline
\end{tabular}




\section{Effect of compost fertilizer on the above-mentioned traits}

Results illustrated in Table 5 revealed that except for proline, sodium, potassium contents, sugar lost to molasses\% and quality index, other traits were significantly affected by increasing compost level from zero up to 6 ton/fed. An application of 6-ton compost/fed gave the thickest, heaviest roots and the highest values of sucrose and extractable sugar percentages, root and sugar yields/fed. Meantime, alpha-amino $\mathrm{N}$ content decreased in $1^{\text {st }}$ season and the second one. Applying 6-ton compost/fed significantly increased root weight amounted to 0.04 and $0.11 \mathrm{~g} / \mathrm{plant}$ and was accompanied by an increase in root and sugar yields/fed amounted to 3.87 $\%$-ton roots and $8.66 \%$ tons sugar in $1^{\text {st }}$ season, while $4.51 \%$-ton roots and $9.97 \%$-ton sugar in $2^{\text {nd }}$ season over that those gained 4-ton compost/fed. These results coincide with that obtained by Makhlouf $\boldsymbol{e t}$ al., (2021) and Wallace and Carter (2007) who explained the effect of compost on the yield of sugar beet on various soil types (sandy loam, clay loam, sandy clay loam and sandy silt loam). They showed that the application of compost improves soil fertility. Key benefits were quantified relating to the physical condition of the soil (organic matter, soil structure and water relations); soil chemistry (soil pH and nutrients) and soil biology (increased microbial populations and activity).

Table 5: Some traits of the tested sugar beet varieties as affected by compost levels in 2018/2019 and 2019/2020 seasons.

\begin{tabular}{|c|c|c|c|c|c|c|c|c|c|c|c|c|}
\hline \multirow{3}{*}{$\begin{array}{c}\text { Compost } \\
\text { levels } \\
(\text { ton/fed })\end{array}$} & \multicolumn{12}{|c|}{ 2018/2019 season } \\
\hline & \multirow{2}{*}{$\begin{array}{r}\text { Proline } \\
(\mu \text { moles } g)\end{array}$} & \multirow{2}{*}{$\begin{array}{l}\begin{array}{l}\text { Root } \\
\text { diameter } \\
(\mathbf{c m})\end{array} \\
\end{array}$} & \multirow{2}{*}{$\begin{array}{c}\text { Root } \\
\text { weight } \\
\text { (kg) }\end{array}$} & \multirow{2}{*}{$\begin{array}{c}\text { Sucrose } \\
\%\end{array}$} & Alpha & $\mathrm{Na}$ & $\mathbf{K}$ & \multirow{2}{*}{ SLM\% } & \multirow{2}{*}{ ES\% } & \multirow{2}{*}{ QZ } & \multirow{2}{*}{$\begin{array}{l}\text { Root } \\
\text { yield/fed } \\
\text { (ton) }\end{array}$} & \multirow{2}{*}{$\begin{array}{c}\text { Sugar } \\
\text { yield/fed } \\
\text { (ton) }\end{array}$} \\
\hline & & & & & \multicolumn{3}{|c|}{ contents } & & & & & \\
\hline $\mathbf{0}$ & 4.20 & 8.43 & 0.59 & 15.72 & 1.64 & 3.97 & 2.72 & 1.71 & 13.41 & 85.31 & 14.81 & 1.99 \\
\hline 2 & 3.30 & 8.65 & 0.62 & 16.21 & 1.49 & 2.38 & 2.69 & 1.67 & 14.06 & 86.74 & 16.98 & 2.37 \\
\hline 4 & 2.60 & 9.25 & 0.64 & 16.46 & 1.44 & 2.23 & 2.56 & 1.58 & 14.30 & 86.88 & 17.81 & 2.54 \\
\hline 6 & 2.40 & 9.90 & 0.68 & 17.05 & 1.37 & 2.20 & 2.23 & 1.54 & 14.82 & 86.92 & 18.50 & 2.76 \\
\hline $\begin{array}{l}\text { LSD at } \\
\mathbf{5 \%}\end{array}$ & NS & 0.66 & 0.04 & 0.06 & 0.06 & NS & NS & NS & 0.18 & NS & 0.95 & 0.06 \\
\hline \multicolumn{13}{|c|}{ 2019/2020 season } \\
\hline $\mathbf{0}$ & 3.20 & 9.74 & 0.66 & 15.32 & 1.76 & 2.21 & 2.85 & 1.45 & 13.25 & 86.49 & 16.70 & 2.22 \\
\hline 2 & 2.30 & 10.00 & 0.72 & 16.01 & 1.53 & 2.15 & 2.74 & 0.80 & 13.89 & 86.76 & 19.29 & 2.82 \\
\hline 4 & 1.80 & 10.25 & 0.76 & 16.66 & 1.51 & 2.24 & 2.55 & 0.81 & 14.48 & 86.91 & 20.39 & 3.11 \\
\hline 6 & 1.60 & 11.30 & 0.87 & 17.46 & 1.22 & 2.36 & 2.37 & 0.83 & 15.22 & 87.17 & 21.31 & 3.42 \\
\hline $\begin{array}{l}\text { LSD at } \\
\mathbf{5 \%}\end{array}$ & NS & 1.00 & 0.10 & 0.09 & 0.13 & NS & NS & NS & 0.05 & NS & 0.90 & 0.10 \\
\hline
\end{tabular}

Alpha $=\alpha$-amino nitrogen content, $\mathrm{Na}=$ Sodium and $\mathrm{K}=$ Potassium contents. $\mathrm{SLM}=$ Sugar lost in molasses \%, ES= Extractable sugar\%, $\mathrm{QZ}=\mathrm{Quality}$ index. 
The interaction between compost fertilization levels and sugar beet varieties:

Among the studied traits only, root diameter, fresh weight/plant, and yield/fed (ton) were significantly affected by the interaction between compost levels and the evaluated varieties in both seasons (Table 6). The highest value of root diameter, fresh weight/plant, and yield/fed (12.30 $\mathrm{cm}, 0.955 \mathrm{~g}$, and $21.72 \mathrm{ton} / \mathrm{fed})$ were produced from fertilized monogerm (Indira-KWS) variety with 6 ton/fed compost in 1st season. In the second one, the mono-germ variety (Indira-KWS) had the same trend, it was surpassed the all rest of the varieties and achieved the highest values of the previously mentioned traits. These increases were clearly magnitude when mono-germ varieties fertilized with this level (6 ton/fed) compared to all multi or mono-germ varieties. These results may be attributed to the positive effect of compost in increased total microbial count in soil amended with organic matter which indicated the act of simple organic carbon compounds found in compost that were readily assimilated by microorganisms as well as, the difference in their genetic structure and the chemical properties of soil of the experimental site. These results are in line with those obtained with El-Nagdi and Abd El

Fattah (2011), Enan, et al., (2016), and Makhlouf et al., (2021).

Table 6: Interaction effect between sugar beet varieties and compost levels on root traits during two seasons.

\begin{tabular}{|c|c|c|c|c|c|c|c|c|c|c|c|c|}
\hline \multirow{4}{*}{$\begin{array}{c}\text { Sugar beet } \\
\text { varieties }\end{array}$} & \multicolumn{12}{|c|}{ 2018/2019 season } \\
\hline & \multicolumn{4}{|c|}{ Root diameter } & \multicolumn{4}{|c|}{ Root weight } & \multicolumn{4}{|c|}{ Root Yield } \\
\hline & \multicolumn{12}{|c|}{ Compost levels (ton /fed) } \\
\hline & $\mathbf{0}$ & 2 & 4 & 6 & $\mathbf{0}$ & 2 & 4 & 6 & $\mathbf{0}$ & 2 & 4 & 6 \\
\hline Indira & 9.67 & 9.67 & 10.87 & 12.30 & 0.827 & 0.835 & 0.903 & 0.955 & 18.11 & 21.41 & 21.63 & 21.72 \\
\hline Dipendra & 9.13 & 9.40 & 10.76 & 11.17 & 0.620 & 0.621 & 0.635 & 0.648 & 16.40 & 19.31 & 19.54 & 20.16 \\
\hline Carma & 9.47 & 10.03 & 10.20 & 11.33 & 0.603 & 0.637 & 0.665 & 0.757 & 18.08 & 20.43 & 20.55 & 21.62 \\
\hline Vangelis & 9.27 & 9.47 & 9.89 & 10.40 & 0.570 & 0.627 & 0.637 & 0.650 & 16.05 & 18.02 & 19.63 & 21.34 \\
\hline Shantala & 9.63 & 9.83 & 10.47 & 11.57 & 0.638 & 0.682 & 0.729 & 0.770 & 15.93 & 18.97 & 19.32 & 20.35 \\
\hline Melodia & 10.37 & 10.81 & 11.07 & 11.73 & 0.782 & 0.858 & 0.893 & 0.911 & 16.48 & 18.90 & 21.03 & 21.87 \\
\hline MK 4199 & 9.90 & 10.00 & 10.70 & 10.73 & 0.641 & 0.688 & 0.696 & 0.756 & 17.39 & 18.78 & 20.81 & 20.92 \\
\hline Shrb21802 & 9.33 & 9.57 & 9.67 & 11.2 & 0.562 & 0.633 & 0.767 & 0.797 & 17.59 & 19.01 & 19.31 & 20.98 \\
\hline LSD at $5 \%$ & \multicolumn{4}{|c|}{0.42} & \multicolumn{4}{|c|}{0.14} & \multicolumn{4}{|c|}{1.09} \\
\hline \multicolumn{13}{|c|}{$2019 / 2020$ season } \\
\hline Indira & 10.07 & 10.25 & 11.09 & 11.82 & 0.563 & 0.644 & 0.649 & 1.016 & 19.00 & 19.45 & 21.65 & 21.94 \\
\hline Dipendra & 9.20 & 10.13 & 10.93 & 10.93 & 0.535 & 0.597 & 0.598 & 0.684 & 16.10 & 19.31 & 19.89 & 20.69 \\
\hline Carma & 9.52 & 9.70 & 10.51 & 11.07 & 0.524 & 0.576 & 0.610 & 0.633 & 16.70 & 20.3 & 20.51 & 21.44 \\
\hline Vangelis & 9.17 & 9.87 & 10.23 & 10.27 & 0.853 & 0.884 & 0.908 & 0.956 & 16.90 & 18.58 & 19.62 & 21.62 \\
\hline Shantala & 9.73 & 10.21 & 10.53 & 11.70 & 0.718 & 0.744 & 0.827 & 0.897 & 15.50 & 18.15 & 19.40 & 20.72 \\
\hline Melodia & 10.55 & 10.73 & 10.93 & 11.43 & 0.805 & 0.830 & 0.913 & 0.984 & 16.45 & 18.61 & 21.04 & 21.70 \\
\hline MK 4199 & 10.08 & 10.57 & 10.87 & 11.23 & 0.699 & 0.725 & 0.811 & 0.879 & 15.36 & 20.18 & 20.61 & 20.85 \\
\hline Shrb21802 & 9.63 & 9.70 & 10.47 & 11.17 & 0.607 & 0.784 & 0.788 & 0.901 & 17.56 & 19.71 & 20.38 & 21.48 \\
\hline LSD at $5 \%$ & \multicolumn{4}{|c|}{0.11} & \multicolumn{4}{|c|}{0.20} & \multicolumn{4}{|c|}{0.84} \\
\hline
\end{tabular}


Sucrose $\%$, extractable sugar $\%$, and sugar yield were affected significantly by the interaction between compost levels and sugar beet varieties (Table 7). Results found a significant difference between monogerm variety (Indira-KWS) and all tested varieties whether these varieties are mono or multi-germ in sucrose $\%$ trait when it was fertilized with 6ton compost/fed in $1^{\text {st }}$ season only. However, in the second season, Shrb21802 and Melodia multi-germ varieties without a significant difference between them showed better performance and gave the highest values of sucrose $\%$ in both seasons, extractable sugar \% and sugar yield/fed in $2^{\text {nd }}$ season only compared to other mono or multi varieties of embryos when they received the higher dose of compost (6 ton/fed). These results may be due to variable genetic structure, positively interacted with the mentioned compost levels. These results coincide with those obtained by (Masri et al., 2015), Abu-Ellail et al., (2020), and EL-Kady et al., (2021) who found sugar beet varieties differed significantly in sucrose $\%$, extractable sugar\% and sugar yields.

Table 7: Interaction effect between sugar beet varieties and compost levels on quality traits during two seasons.

\begin{tabular}{|c|c|c|c|c|c|c|c|c|c|c|c|c|}
\hline \multirow{4}{*}{$\begin{array}{c}\text { Sugar beet } \\
\text { varieties }\end{array}$} & \multicolumn{12}{|c|}{ 2018/ 2019 season } \\
\hline & \multicolumn{4}{|c|}{ Sucrose \% } & \multicolumn{4}{|c|}{ Extractable sugar \% } & \multicolumn{4}{|c|}{ Sugar Yield (ton/fed) } \\
\hline & \multicolumn{12}{|c|}{ Compost levels (ton /fed) } \\
\hline & $\mathbf{0}$ & 2 & 4 & 6 & $\mathbf{0}$ & 2 & 4 & 6 & $\mathbf{0}$ & 2 & 4 & 6 \\
\hline Indira & 16.24 & 16.27 & 16.70 & 17.80 & 14.17 & 14.18 & 14.47 & 15.55 & 2.57 & 3.04 & 3.13 & 3.38 \\
\hline Dipendra & 15.55 & 16.08 & 16.19 & 17.22 & 13.35 & 13.81 & 14.11 & 15.11 & 2.19 & 2.67 & 2.76 & 3.05 \\
\hline Carma & 15.33 & 15.86 & 16.07 & 16.99 & 13.26 & 13.62 & 13.92 & 14.82 & 2.40 & 2.78 & 2.86 & 3.20 \\
\hline Vangelis & 15.68 & 16.21 & 16.62 & 17.39 & 13.71 & 14.07 & 14.39 & 15.19 & 2.20 & 2.54 & 2.82 & 3.24 \\
\hline Shantala & 16.39 & 16.93 & 16.97 & 17.01 & 14.28 & 14.89 & 14.91 & 14.91 & 2.27 & 2.82 & 2.88 & 3.03 \\
\hline Melodia & 15.35 & 16.01 & 16.63 & 16.72 & 13.24 & 13.83 & 14.37 & 14.54 & 2.18 & 2.61 & 3.02 & 3.18 \\
\hline MK 4199 & 15.60 & 16.22 & 16.26 & 16.31 & 13.54 & 13.92 & 14.01 & 14.18 & 2.35 & 2.61 & 2.92 & 2.97 \\
\hline Shrb21802 & 15.60 & 16.06 & 16.27 & 16.93 & 13.39 & 13.91 & 14.10 & 14.61 & 2.36 & 2.64 & 2.72 & 3.07 \\
\hline \multirow[t]{2}{*}{ LSD at $5 \%$} & \multicolumn{4}{|c|}{0.24} & \multicolumn{4}{|c|}{0.06} & \multicolumn{4}{|c|}{$\mathbf{0 . 0 3}$} \\
\hline & \multicolumn{12}{|c|}{ 2019/2020 season } \\
\hline Indira & 14.23 & 15.97 & 17.29 & 17.48 & 12.01 & 13.58 & 14.69 & 15.06 & 2.28 & 2.64 & 3.18 & 3.27 \\
\hline Dipendra & 15.74 & 15.79 & 16.16 & 16.46 & 13.43 & 13.50 & 13.80 & 14.10 & 2.16 & 2.61 & 2.74 & 2.92 \\
\hline Carma & 14.99 & 15.63 & 16.30 & 17.34 & 12.63 & 13.48 & 14.02 & 15.03 & 2.11 & 2.74 & 2.88 & 3.22 \\
\hline Vangelis & 16.11 & 16.06 & 17.18 & 17.36 & 13.75 & 13.80 & 14.89 & 15.02 & 2.32 & 2.56 & 2.92 & 3.25 \\
\hline Shantala & 15.51 & 16.08 & 17.05 & 17.10 & 13.17 & 13.44 & 14.87 & 15.31 & 2.04 & 2.44 & 2.88 & 3.17 \\
\hline Melodia & 16.26 & 16.83 & 16.95 & 18.51 & 13.94 & 14.20 & 14.63 & 16.17 & 2.29 & 2.64 & 3.08 & 3.55 \\
\hline MK 4199 & 15.44 & 15.85 & 16.42 & 16.42 & 13.13 & 13.56 & 13.83 & 14.18 & 2.02 & 2.74 & 2.85 & 2.96 \\
\hline Shrb21802 & 14.27 & 15.89 & 15.95 & 18.97 & 11.97 & 13.48 & 13.66 & 16.58 & 2.10 & 2.66 & 2.78 & 3.56 \\
\hline LSD at $5 \%$ & \multicolumn{4}{|c|}{0.89} & \multicolumn{4}{|c|}{0.92} & \multicolumn{4}{|c|}{0.14} \\
\hline
\end{tabular}




\section{Genotype by Trait (GT) biplot graph}

The polygon view of a genotype by trait (GT) biplot graph is an effective tool to study the interaction patterns between genotypes and traits provided the biplot should explain a high percentage of the total variation. The biplot graph (Fig. 1) presents the relationship among the aimed sugar beet genotypes using the root and sugar yields and their related attributes. The GT biplot of the mean performance of the sugar beet data in $1^{\text {st }}$ season explained $86.33 \%$ of the total variation of the standardized data. The first and two principal components (PC1 and PC2) explained $57.73 \%$ and $28.6 \%$, respectively. While in the $2^{\text {nd }}$ season, total variation equaled $82.77 \%$ and the first and two principal components (PC1 and PC2) explained 56.69\% and 26.08\%, respectively. This relatively moderate proportion reflects the complexity of the relationships among the genotypes and the measured traits. Yan and Kang (2003) mentioned that the first two PC's should reflect more than $60 \%$ of the total variation in order to achieve the goodness of fit for GT biplot model. The perpendicular lines to the polygon sides facilitate comparison between neighboring vertex varieties. It is obvious that variety Indira-KWS recorded high values of root yield (RY), sugar yield (SY) and related traits. Also, varieties Carma and Melodia located in the same sector and reflected similar behavior toward the same traits. It is noted that the points of these varieties and traits placed into one sector and the angles among them were acutely reflecting the positive associations among them. On the other hand, the four varieties (Dipendra-KWS, Vangelis, Shantala-KWS and MK 4199) recorded the lowest values of RY and SY because obtuse angles were found between these genotypes and the two characters. It is worth mentioning that the current varieties groups are consistent with those obtained by the mean performance. Accordingly, the GT biplot graph is considered a successful and effective technique to select the best variety for muti-traits. Undoubtedly, GT biplot graph is preferred because it easy to interpret and more informative. These results are in line with Korshid, (2016), Ober et al., (2005), and Abbasi et al., (2014) who found that GT biplot showed that yield-related traits (i.e., root and sugar yields/fed) had the same discriminating values for the genotypes as did the extraction coefficient of sugar content, and sugar extractable percentage. Traits with short vectors were less variable among varieties. 

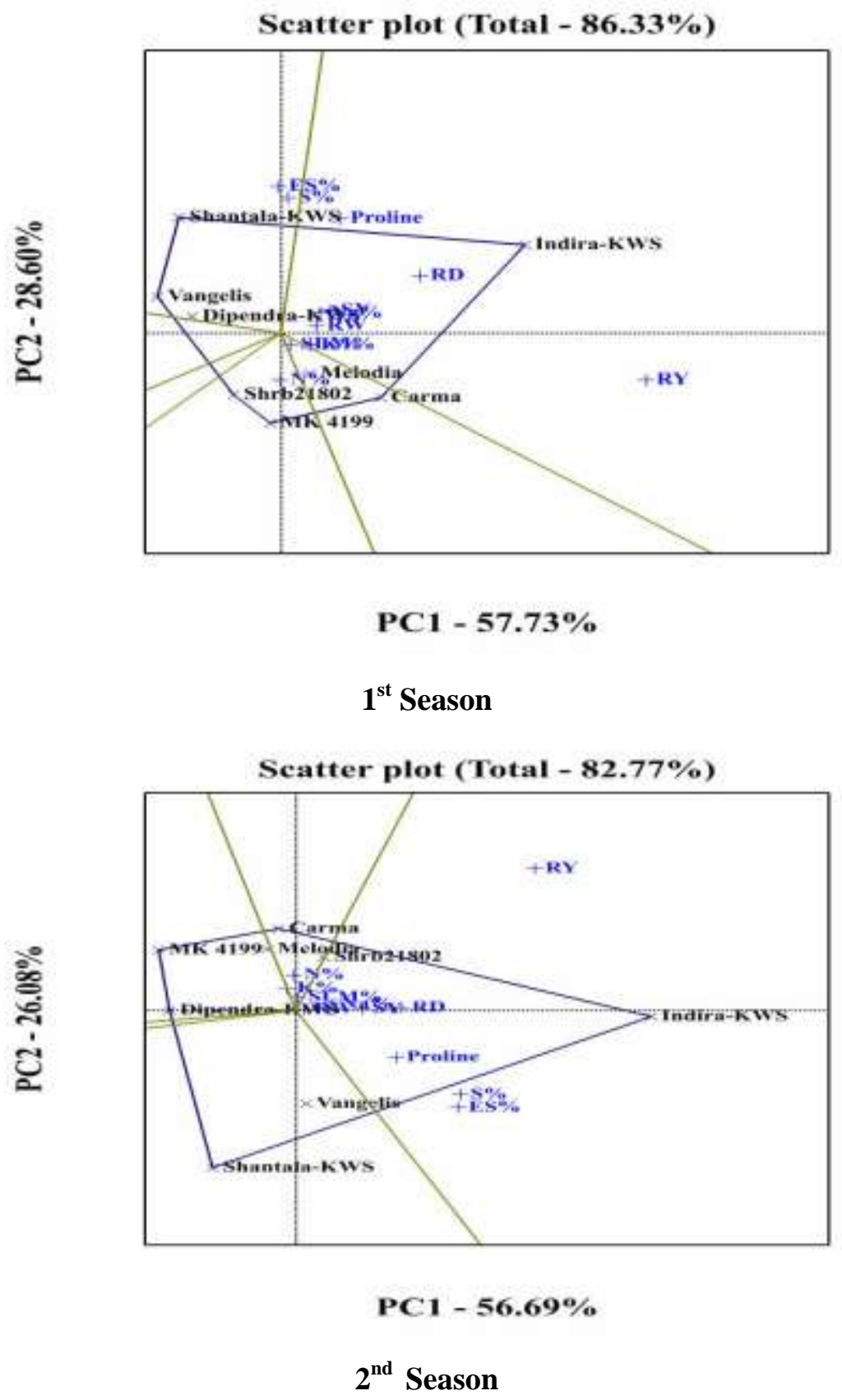

Fig. (1): Polygon view Genotype by Trait (GT) biplot showing which varieties had the highest values for which traits for eight sugar beet varieties at $1^{\text {st }}$ and $2^{\text {nd }}$ season respectively. 


\section{Genotypes by treatments (GT) biplot graph}

Data in Fig. 2 and 3 showed the polygon view of a genotype by treatments (GT) biplot graph. Figure 2 cleared the GT biplot for the sugar beet dataset of root yield explained 88.17 and $88.40 \%$ of the total variation in the first and the second years, respectively. The first two PC's (PC1 and PC2) explained 71.60 and $16.58 \%$, respectively while the first two PC's described 64.97 and $23.43 \%$, respectively. With respect to sugar yield dataset, Figure 3 showed that GT biplot graph explained $84.84 \%$ and $84.89 \%$ of the total variation in the first and the second years, respectively. The first two PC's (PC1 and PC2) accounted for about $(68.55 \%$ and $16.29 \%)$ in $1^{\text {st }}$ season and $(63.47 \%$ and $21.03 \%)$ in $2^{\text {nd }}$ season of the total variation, respectively. This relatively high percentage reflects the efficiency of GT biplot graph in interpreting the responsibility of sugar beet varieties to the treatments for root and sugar yields at both experimental years. The polygon view of the GT biplot helps identify varieties (genotypes) with good responsibility for one or more treatments. Results showed that variety (Indira-KWS) gave the best root and sugar yields under most or all treatments in $1^{\text {st }}$ and $2^{\text {nd }}$ seasons followed by variety Carma in the $1^{\text {st }}$ season and variety Sharb21802 and Melodia in the $2^{\text {nd }}$ season. These results are in agreement with Ober $\boldsymbol{e t}$ al., (2005) and Korshid, (2016) who found that genotype $\times$ trait biplots (GT) showed superior genotypes with relatively greater expression of combinations of favorable traits. The results suggest that root weight and patterns of water use could help identify elite sugar beet varieties. These data should enable tools to be developed for the indirect determination of varieties suited to stress environments.

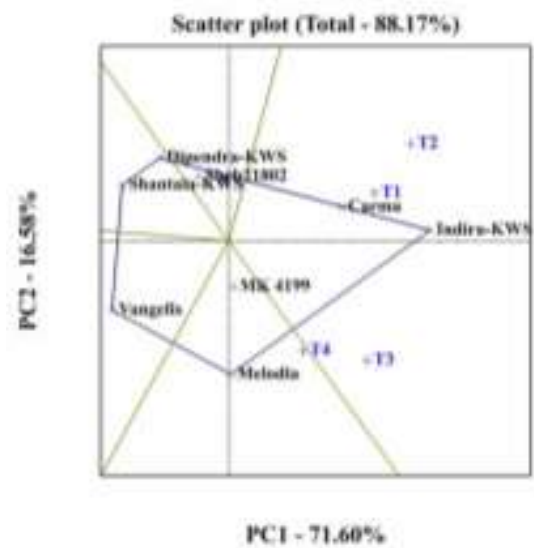

Root yield in $1^{\text {st }}$

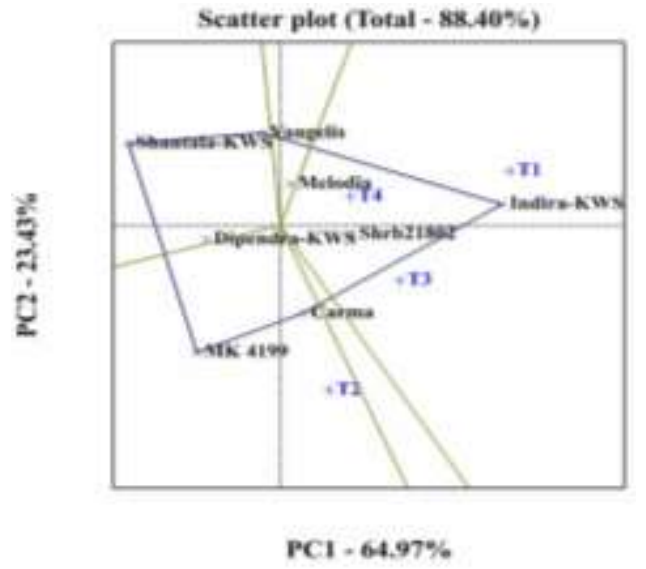

Root yield in $2^{\text {nd }}$

Fig. (2): Polygon view of genotype $\times$ treatments biplot of eight sugar beet varieties for root yield at the $1^{\text {st }}$ and $2^{\text {nd }}$ season. 


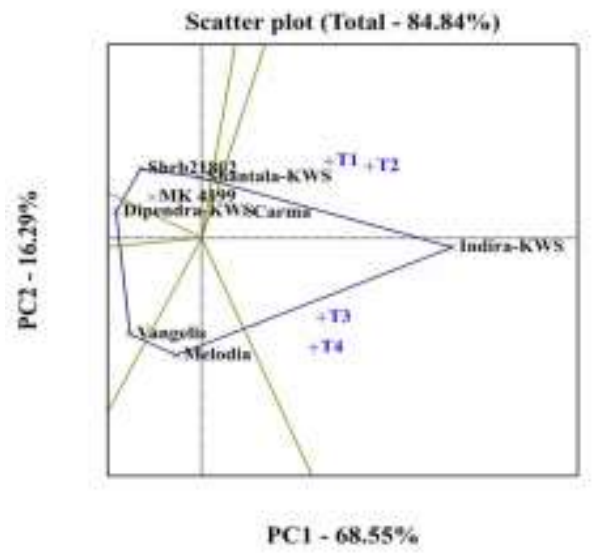

Sugar yield in $1^{\text {st }}$

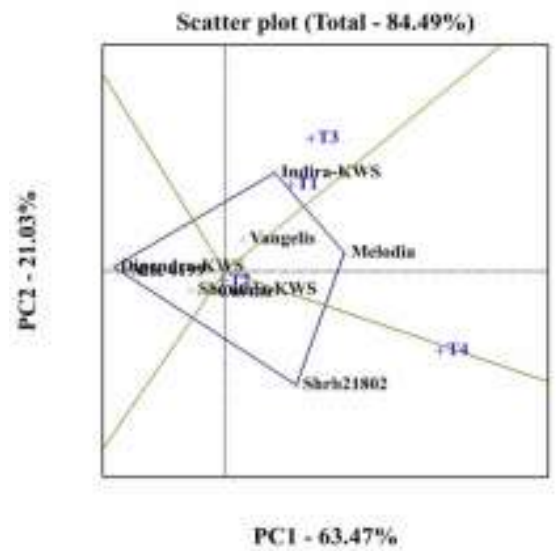

Sugar yield in $2^{\text {nd }}$

Fig. (3): Polygon view of genotype $\times$ treatments biplot of eight sugar beet varieties for sugar at the $1^{\text {st }}$ and $2^{\text {nd }}$ season.

\section{Relationships among yield-trait combinations}

Data are given in Table 8 presents the simple correlation coefficients among root and sugar yields and their related attributes estimated across the two seasons. The results showed that there was a significant positive correlation between RY and each of RD $\left(0.284^{*}\right)$, RW $\left(0.411^{*}\right)$, and SY $\left(0.800^{* *}\right)$. It is suggested that the RY of these sugar beet varieties may be raised through selection for the biggest root and those that had the highest fresh root weight. However, insignificant and positive associations were obtained between RY and the other traits indicating that these traits may be independent in their genetic behavior under the tested varieties. The yield components exhibited various trends of associations among themselves. Highly significant and positive associations were observed among S\%, ES\%, and SY (correlation coefficients $>0.25$ ) reporting that the highest root yield varieties were highly sucrose $\%$, extractable sugar $\%$, and sugar yield. The highest sucrose $\%$ and extractable sugar $\%$ varieties produced the lowest $\alpha$-amino-N, Na, K, and MLS\% according to the highly significant negative associations between extractable sugar \% and each of MLS\% (-0.656**) and $\alpha$-amino-N $(-0.554 *)$. It is worthy to understand the negative associations between proline accumulation and each of RD (-0.003), S\%($0.234)$, and ES\%(-0.320). This trend of interrelationships among yield attributes sometimes called offset, buffer, or compensation effects. This relation means that increasing sucrose \% or extractable sugar\% did not necessarily result in a high Proline. On the other hand, the magnitude of the 
correlation coefficients among other traits was trivial and insignificant. These results concur with those reported by Sklenar et al., (1997), AbuEllail et al., (2020) and Danojević et al., (2011) they found a significant and positive correlations were obtained for root weight and root yield. Also reported that extractable sugar $\%$ and root yield in both seasons were significantly $(\mathrm{P} \leq 0.01)$ contributed to variations in sugar yield (ton/fed).

Table (8): Correlation coefficients among root and sugar yields/fed and its related attributes computed from eight sugar beet varieties evaluated in both seasons.

\begin{tabular}{|c|c|c|c|c|c|c|c|c|c|c|c|}
\hline & RD & RW & RY & S\% & ES\% & SY & $\mathbf{N}$ & $\mathrm{Na}$ & $\mathbf{K}$ & MLS\% & Proline \\
\hline RD & 1 & & & & & & & & & & \\
\hline RW & $0.365 *$ & 1 & & & & & & & & & \\
\hline RY & 0.284* & 0.411* & 1 & & & & & & & & \\
\hline S\% & 0.063 & -0.183 & 0.103 & 1 & & & & & & & \\
\hline ES\% & 0.023 & -0.253 & 0.048 & $0.992 * *$ & 1 & & & & & & \\
\hline SY & 0.366 & 0.424 & $\mathbf{0 . 8 0 0} * *$ & 0.279* & $0.215^{*}$ & 1 & & & & & \\
\hline $\mathbf{N}$ & -0.175 & 0.012 & 0.238 & $-0.554 *$ & $-0.556 *$ & \begin{tabular}{|c|}
-0.080 \\
\end{tabular} & 1 & & & & \\
\hline $\mathrm{Na}$ & -0.293 & 0.120 & 0.531 & 0.243 & 0.185 & 0.441 & \begin{tabular}{|l|}
0.126 \\
\end{tabular} & 1 & & & \\
\hline $\mathbf{K}$ & 0.704 & \begin{tabular}{|l|}
0.410 \\
\end{tabular} & \begin{tabular}{|l|}
0.191 \\
\end{tabular} & -0.213 & \begin{tabular}{|l|}
-0.249 \\
\end{tabular} & \begin{tabular}{|l|}
0.115 \\
\end{tabular} & \begin{tabular}{|l|}
-0.012 \\
\end{tabular} & \begin{tabular}{|l|}
-0.288 \\
\end{tabular} & 1 & & \\
\hline MLS\% & 0.319 & $0.532 *$ & 0.171 & $-0.656 * *$ & $-\mathbf{0 . 7 3 0} * *$ & \begin{tabular}{|l|}
0.267 \\
\end{tabular} & \begin{tabular}{|l|}
0.334 \\
\end{tabular} & 0.030 & 0.477 & 1 & \\
\hline Proline & \begin{tabular}{|l|}
-0.003 \\
\end{tabular} & 0.276 & 0.152 & -0.234 & \begin{tabular}{|l|}
-0.320 \\
\end{tabular} & \begin{tabular}{|l|}
0.428 \\
\end{tabular} & \begin{tabular}{|l|}
-0.033 \\
\end{tabular} & 0.384 & \begin{tabular}{|l|}
-0.108 \\
\end{tabular} & $0.595 *$ & 1 \\
\hline
\end{tabular}

\section{CONCLUSION}

The obtained results by GT biplot graphs have coincided with those obtained by correlation matrix, indicating that the GT biplot graph is considered a successful and effective technique besides. Undoubtedly, the GT biplot graph is preferred because it is easy to interpret and gives more information. The varieties with the best performance for each group were (mono-germ varieties Indira-KWS and Carma as well multi-germ variety Melodia). The combination between root and sugar yields with proline and MLS should not be used to select varieties with good performance for the other groups of related yield traits. Correlation exhibits a high effect of root diameter, and root weight at harvest on root yield in crops.

\section{REFERENCES}

Abbasi, Z.; A. Arzani and M.M. Majidi (2014). Evaluation of Genetic Diversity of Sugar Beet (Beta vulgaris L.) Crossing Parents Using Agro-morphological Traits and Molecular Markers. J. Agr. Sci. Tech., 16: 1397-1411.

Abu-Ellail, F.F.B.; K.A. Sadek and E.H.S. El-Laboudy (2020). Yield and quality of some sugar beet varieties as affected by humic acid application rates under sandy soil condition. J. of Plant Production, Mansoura Univ., 11 (9):791-79. 
Ali, A.A.M. (2015). Sugar beet productivity as affected by nitrogen fertilizer and foliar spraying with boron. Int. J. Curr. Microbiol. App. Sci., 4 (4): 181- 196.

Annual Report for Sugar Crops, (2020). Launched by Sugar Crops Council, Ministry of Agriculture and Land Reclamation, Giza, Egypt.

A.O.A.C. (2005). Association of Official Analytical Chemists. Official methods of analysis, 26th Ed. A.O.A.C., Int., Washington, D.C; USA.

Ashraf, M. and P.J.C. Harris (2004). Potential biochemical indicators of salinity tolerance in plants. Plant Sci., 166: 3-6.

Azizpour, K.; M.R. Shakira; K.S.N. Khosh; H. Alyari; M. Moghaddam; E. Esfandiari and M. Pessarakli (2010). Physiological response of spring durum wheat genotypes to salinity. J. Plant Nutr., 33: 859-873.

Bates, L.S.; R.P. Waldren and I.D. Teare (1973). Rapid determination of free proline for water stress studies. Plant Soil, 39:205-207.

Cooke, D.A. and R.K. Scott (1993). The Sugar Beet Crop. Science into Practice Published by Chapman and Hall, London, pp: 262-265.

Danojević, D.; Ž. Ćurčić; N. Nagl and L. Kovačev (2011). Correlations of root traits in monogerm sugar beet from open pollination and their variability. Ratar. Povrt. / Field Veg. Crop Res., 48: 333-340.

David, F. (2007). Salt accumulation processes. North Dakota state Univ., Fargo ND 58105.

Devillers, P. (1988). Prevision du sucre melasse sucrerie franases 190200. (C.F. The Sugar Beet Crop. Book).

Dexter, S.T.; M.G. Frankes and F.W. Snyder (1967). A rapid and practical method of determining extractable while sugar as may be applied to the evaluation of agronomic practices and grower deliveries in the sugar beet industry. J. Am. Soc. Sugar beet Technol., 14: 433 - 454.

El-Kady, M.S.; F.F.B. Abu-Ellail and E.H.S. El-Laboudy (2021). Evaluation of some sugar beet varieties under water salinity stress in new reclaimed land. J. of Plant Production, Mansoura Univ., 12 (1):63-72.

El-Nagdi, W.M.A. and A.I. Abd El Fattah (2011). Controlling rootknot nematode, meloidogyne incognita infecting sugar beet using some plant residues, a bio fertilizer, compost and biocides. J. of Plant Protection Research, 51 (2): 107-113. 
Enan, S.A.A.M.; E.F.A Aly and A.I. Badr (2016). Effect of humic acid and potassium on yield and quality of some sugar beet varieties in sandy soil. J. of Plant Production Mansoura Univ., 7(2): 289- 297.

Falconer, D.S. (1989). Introduction to Quantitative Genetics. $3^{\text {rd }}$ ed., Longman Scientific \& Technical, London., Pp 448.

Francis, C.A. and H. Daniel (2004). Organic Farming: 77-84. Encyclopedia of soils in the environment. Elsevier, Oxford, UK.

Ghoulam, C.; A. Foursy and K. Fares (2002). Effects of salt stress on growth, inorganic ions and proline accumulation in relation to osmotic adjustment in five sugar beet cultivars. Environ Exp Bot., 47:39-50.

Jackson, M.L. (1973). Soil Chemical Analysis. Englewood Cliffs, New Jersey: Prentice Hall.

Khan, A.H.; M.Y. Ashraf; S.S.M. Naqvi; B. Khanzada and M. Ali (1995). Growth and ion and solute contents of sorghum grown under $\mathrm{NaCl}$ and $\mathrm{Na}_{2} \mathrm{SO}_{4}$ salinity stress. Acta Physiol. Plant, 17: 261-8.

Korshid A. (2016). Biplot analysis of salinity tolerance indices in sugar beet breeding lines. Adv Plants Agric Res., 5(2):495-499.

Mahmoud, E.A.; B.S.H. Ramadan; I.H. El-Geddawy and S.F. Korany (2014). Effect of mineral bio fertilization on productivity of sugar beet. J. Plant Production, Mansoura Univ., 5(4): 699-710.

Makhlouf, B.S.I.; E.H.S. El-Laboudy and F.F.B. Abu-Ellail (2021). Effect of $\mathrm{N}$-fixing bacteria on nitrogen fertilizer requirements for some sugar beet varieties. J. of Plant Production, Mansoura Univ., 12(1):87-96.

Masri, M.I.; B.S.B. Ramadan; A.M.A. El-Shafai and M.S. El-Kady (2015). Effect of water stress and fertilization on yield and quality of sugar beet under drip and sprinkler irrigation systems in sandy soil. Int. J. Agric. Sci., 5(3): 414-425.

Ober, E. S.; M. Le Bloa; C. J.A. Clark; A. Royal; K. W. Jaggard and J. D. Pidgeon (2005). Evaluation of physiological traits as indirect selection criteria for drought tolerance in sugar beet, Field Crops Research, 91 (2-3): 231-249.

Rajaa, F.H and S.K. Saadi (2011). Effect of Gibberellic acid and Organic fertilizer on certain chemical compounds for wheat plant (Triticum aestivum L.). Al-Anbar J. Agric. Sci., 9:70-79. 
Seddik, Wafaa M. A. and K. M. Laila (2004). Effect of some natural soil amendments on some soil physical properties, peanut and carrot yield in sandy soil. Egypt J. Agric. Res., 82 (2):74-90.

Siddiqui, Y.; S. Meon; R. Ismail and M. Rahmani (2009). Biopotential of compost tea from agro waste to suppress Choanephora cucurbitarum L. the causal pathogen of wet rot of okra. Biological Control, 49:38-44.

Sklenar, P.; L. Kovačev and N. Čačić (1997). Root characteristics S3 population of monogram maintainers of cytoplasmic-nuclear male sterility in sugar beet. Sel. Semen., 1-2: 119-126.

Wallace, P. and C. Carter (2007). Effects of compost on yields of winter wheat and barley, sugar beet, onion and swede in the fourth and fifth years of a rotation. Home Growth Cereals Authority Project Report., 422: 31pp.

Yan, W. and I.R. Rajcan (2002). Biplot analysis of test sites and trait relations of soybean in Ontario. Can. J. Plant Sci., 42:11-20.

Yan, W. and M.S. Kang (2003). GGE-biplot analysis: a graphical tool for breeders. Geneticists and Agronomists, CRD Press, Boca Raton.

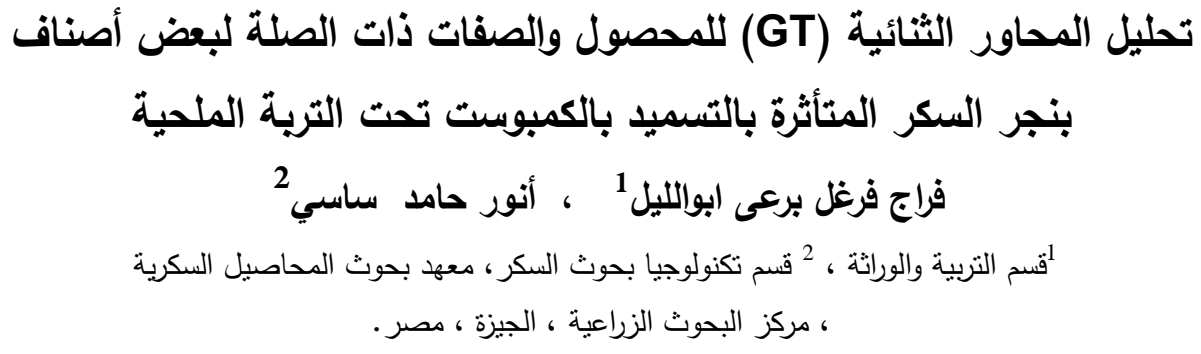


الجذر الطازج للنبات ، ونسبة السكروز ، وإنتاجية محصول الجذور ومحصول السكر للفدان،

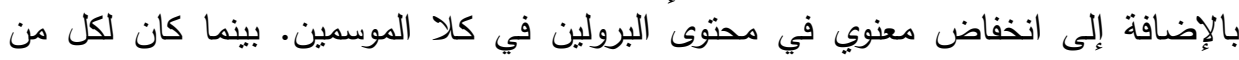

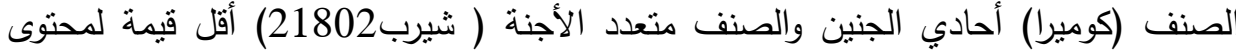

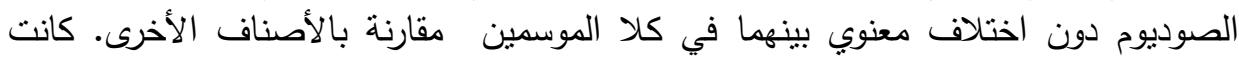

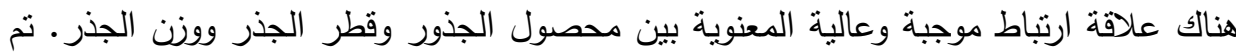

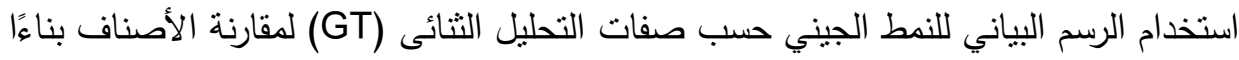

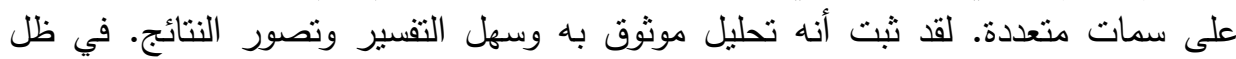
ظروف هذا العمل ، يمكن التوصية بزراعة الصنف أحادي الجنين (أندريا) وتسميده بمعدل

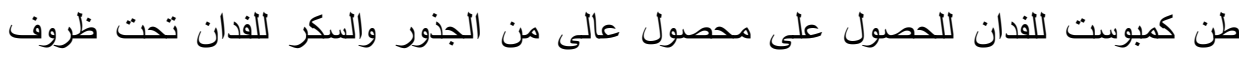
التربة الملحية. 